\title{
Drusen, AMD, and history
}

\author{
Paulus T. V. M. de Jong ${ }^{1,2,3}$
}

Received: 1 August 2015 / Accepted: 19 August 2015 / Published online: 21 September 2015

(C) Springer-Verlag Berlin Heidelberg 2015

It is becoming increasingly difficult to get manuscripts on (ophthalmic) history accepted by medical journals. This, in spite of the fact that studying the history of disorders yields valuable insights, which can offer new approaches to solving problems of pathophysiology or delimiting disease entities. Some authors may not even be aware that a literature search is also a form of historical investigation. Drusen are a case in point. For 160 years drusen have been associated with the aging macula disorder (AMD) -sometimes under a different name-, and are a benchmark for AMD. We still do not know at the present time what role they play in AMD pathogenesis. I was surprised to find out that the association between drusen and AMD was explicitly denied 30 years after their link was first described.

Otto Haab coined the name "senile Macular Disease" (MD) [1] and explicitly wrote that drusen, "quite innocent changes in old persons," had nothing to do with this disease [2] (Fig. 1), although three researchers had earlier linked drusen to MD. So why did Haab come to

Partly presented at the 28th meeting of the Julius Hirschberg Gesellschaft, Bonn, Germany, October 4 2014, and at the joint Cogan - Hirschberg Society meeting, New York, USA March 282015.

Paulus T. V. M. de Jong

p.dejong@nin.knaw.nl

1 Department of Retinal Signal Processing, Netherlands Institute of Neuroscience, KNAW, Meibergdreef 47, 1105

BA Amsterdam, The Netherlands

2 Department of Ophthalmology, Academic Medical Center, Amsterdam, The Netherlands

3 Department of Ophthalmology, Leiden University Medical Center, Leiden, The Netherlands this conclusion? Was it because earlier authors could not agree on where drusen originate from or the effect they had on retinal function? Carl Wedl named drusen as colloid bodies of the choroid and thought they were incompletely developed cells, because they had no cell membrane or nucleus [3]. Frans Donders called them colloid balls surrounded by pigment, noting their preference for the macular area and concluded that drusen originate from retinal pigment epithelial (RPE) cell nuclei [4]. Heinrich Müller mentioned deposits on the inner side of the choroid that had a ball-shaped or drusenoid form and coined the word "druse." [5] $\mathrm{He}$ mentioned that drusen originate from focal thickenings in Bruch's membrane. Later, the theory was formulated that drusen originate from leucocytes [6]. But we still do not know, 160 odd years on, from where exactly drusen originate. The RPE has returned as the latest candidate [7], just as Donders suggested.

Who were these early authors who linked drusen with AMD? Donders designed in 1852 an improved ophthalmoscope after Helmholtz's publication on ophthalmoscopy of the living eye. Donders was convinced that the white flecks that he had seen several times on ophthalmoscopy in eyes of old people suffering from "senile amblyopia" (as loss of visual acuity in the elderly was called at that time) were not fatty metamorphoses but colloid degenerations. Around 1853 Donders started with histological examination of 38 apparently healthy eyes. Drusen rarely were absent in the eyes of persons aged 70 to 80 years. The visual acuity in these eyes had not been carefully recorded before death [4]. Using microscopy Donders noticed rods, obliquely oriented around small drusen as well as degeneration of the choriocapillaris and the RPE. Often rods and cones were absent above drusen, that sometimes compressed the retina, without expanding the retina on the vitreous side. Donders concluded that the 


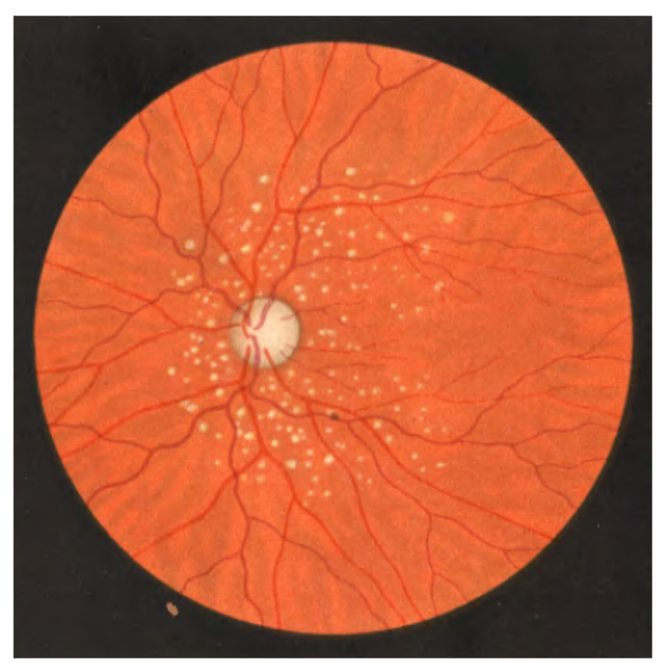

Fig. 1 Drusen of the vitreous membrane of the choroid. Haab wrote: "These drusen, also a change in old age, have nothing to do with the macular disorder depicted here and should be distinctly separated from this" [2]

anatomical relation of the drusen to the retina and the degeneration of the RPE had to have an influence on the retinal function and could lead to visual disturbances [4].

Albrecht Nagel first combined clinical and histological data from the same patient in describing AMD [8]. He recorded in 1868 a 64-year-old woman with a dark-red net and partly confluent white flecks around both maculae complaining about marked "amblyopia," metamorphopsia, and a quivering image. Fine brilliant specks were present, creating the impression of "Krystalldrusen." Nagel published again on her and two more cases in 1875 [9]. His first patient died at age 73 due to an abdominal tumor. The eyes were enucleated 27 hours post mortem and one was put in Müllers fixative. In the nonfixated eye, there were small, sparkling irregularities in the posterior pole on the inner side of the choroid. They contained hard grains with a diameter up to $0.5 \mathrm{~mm}$ that crunched under the tip of a knife. They were markedly similar to the whitish crystal-like drusen seen on ophthalmoscopy. Nagel concluded that the crystalline mass consisted of carbonic acid lime. Lighter round flecks, surrounded by a black pigment ring were seen in the RPE. The flecks were created by drusenoid thickenings of the elastic layer and the outer retinal layer over them was markedly thinner. Nagel thought that this could explain the metamorphopsia and amblyopia of which the patient complained [9].

The third author, Jonathan Hutchinson, depicted a choroid, "speckled with minute dots of yellowish white deposits" [10]. He considered the spots to be "colloid excrescences of the lamina elastica" and wrote: "There is no doubt that the disease is confined to the choroid in the first instance, while the great defect of sight which accompanies it points to implication of the retina secondarily." He formulated three stages in the disease: (1) Scattered yellow-white spots; (2) Coalescence of these to patches with irregular borders; and (3) Hemorrhage at the yellow spot and absorption of the blood. This was a remarkable insight and this transition of drusen to wet AMD is still accepted! Hutchinson mentioned that his friend $\mathrm{Mr}$. Waren Tay "made the ophthalmoscopic examination, and drew my attention to the peculiarities presented" [10].

I found no other articles by Haab, explaining why he decided that senile MD is a separate entity. He concluded from analyzing over 50,000 patient files that senile MD was about as frequent as traumatic MD and myopic macular affection. Senile MD was often bilateral and one should be wary of the outcome of a mature cataract operation when the fellow eye had this MD [11]. I have no idea why he explicitly denied a link between drusen and senile MD. Would an astute observer like Haab still have denied this association, had he known his ophthalmic history?

Acknowledgment Many thanks to P.G.Breen BA HDE for critical comments and translational suggestions.

Conflict of interest No financial support was obtained and there is no conflict of interest.

\section{References}

1. Haab O (1885) Erkrankungen der Macula Lutea. Centralblatt für praktische Augenheilkunde 9:383-384

2. Haab O (1895) Atlas und Grundriss der Ophthalmoskopie und ophthalmoskopischen Diagnostik. Lehmann, München

3. Wedl C (1854) Grundzüge der pathologischen Histologie. Gerold, Wien

4. Donders FC (1855) Beiträge zur pathologischen Anatomie des Auges. Archiv für Ophthalmologie 1:106-118

5. Müller H (1856) Anatomische Beiträge zur Ophthalmologie. Archiv für Ophthalmologie 2:1-100

6. Rudnew A (1871) Ueber die Enstehung der sogenannten Glaskörper der Choroides des menschlichen Auges und über das Wesen der hyalinen Degeneration der Gefässe derselben. Virchow Archiv 53:455-465

7. Rossberger S, Ach T, Best G, Cremer C, Heintzmann R, Dithmar S (2013) High-resolution imaging of autofluorescent particles within drusen using structured illumination microscopy Br. J Ophthalmol 97:518-523

8. Nagel A (1868) Ueber Chorioiditis areolaris und über Krystalle im Augenhintergrund. Klin Monbl Augenheilk 4:417-420

9. Nagel A (1875) Hochgradige Amblyopie, bedingt durch glashäutige Wucherungen und krystallinische Kalkablagerungen an der Innenfläche der Aderhaut. K1 Monatsbl Augenh 13:338-351

10. Hutchinson J (1874) Symmetrical central choroido-retinal disease occurring in senile persons. Royal London Ophthalmic Hospital Rec J Ophthalmic Med Surg 8:231-244

11. Haab O (1888) Ueber die Erkrankung der Macula lutea. Proceedings VII Intern ophthal Congress, Heidelberg, pp 429-435 